\title{
KONSUMSI TABLET FE DAN PENGETAHUAN BERHUBUNGAN DENGAN ANEMIA PADA IBU HAMIL TRIMESTER III
}

\author{
Eka Ratna Sari, Lusi Andriani, PS.Kurniawati \\ Politeknik Kesehatan Kementrian Kesehatan Bengkulu, Jurusan Kebidanan \\ ekars21@gmail.com
}

\begin{abstract}
Anemia in pregnancy is a condition of pregnant woman with hemoglobin $(\mathrm{Hb})$ $<11 \mathrm{gr} \%$ in the first and third trimesters while in the second trimester hemoglobin level $<10,5 \mathrm{gr} \%$. This study aims to determined the factors of the occurrence of anemia in third trimester pregnant women in Kampung Melayu sub-district Bengkulu City 2017.This research uses Analytical Survey design with Cross Sectional Approach. Population in this research is third trimester pregnant woman in Kampung Melayu sub-district as many as 106 people, using sample total sampling technique. The analysis used Chi square test with significance level $\mathrm{p}<0,05$. The results of this study indicate that there is a relationship between adherence of $\mathrm{Fe}(\mathrm{p}=0,000)$ and knowledge $(\mathrm{p}=0,000)$ with anemia occurrence in third trimester pregnant women, no relationship between age $(p=0,346)$, parity $(p=0,949)$ , Education ( $\mathrm{p}=0.198)$, occupation $(\mathrm{p}=1,000)$ with anemia and the most dominant factor with anemia was the consumption of Fe tablet $(\mathrm{OR}=78,803)$. Health workers are expected to provide routine counseling on the causes, symptoms, and effects of anemia for pregnant women and screening anemia by checking $\mathrm{Hb}$ at least twice during pregnancy.
\end{abstract}

Keywords: Anemia, Pregnant, Trimester III, Haemoglobin

\begin{abstract}
Abstrak :Anemia dalam kehamilan adalah kondisi ibu dengan kadar hemoglobin $(\mathrm{Hb})<11$ gr\% pada trimester I dan III sedangkan pada trimester II kadar hemoglobin < 10,5 gr\%. Penelitian ini bertujuan untuk diketahuinya faktor-faktor terjadinya anemia pada ibu hamil trimester III di Kecamatan Kampung Melayu Kota Bengkulu tahun 2017. Desain peneliti ini yaitu SurveiAnalitik dengan pendekatan CrossSectional. Populasi dalam penelitian ini adalah ibu hamil trimester III yang berada di Kecamatan Kampung Melayu sebanyak 106 orang, menggunakan tehnik sampel total sampling. Analisis menggunakan uji Chi square dengan tingkat kemaknaan $\mathrm{p}<0,05$. Hasil penelitian ini menunjukkan bahwa ada hubungan antara kepatuhan konsumsi tablet $\mathrm{Fe}(\mathrm{p}=0,000)$ dan pengetahuan $(\mathrm{p}=0,000)$ dengan kejadian anemia pada ibu hamil trimester III, tidak ada hubungan antara usia $(\mathrm{p}=0,346)$, paritas $(\mathrm{p}=0,949)$, pendidikan $(\mathrm{p}=0,198)$, pekerjaan $(\mathrm{p}=1,000)$ dengan anemia dan faktor yang paling dominan dengan anemia adalah konsumsi tablet $\mathrm{Fe}(\mathrm{OR}=78,803)$. Petugas kesehatan diharapkan memberikan penyuluhan rutin tentang, penyebab, gejala dan dampak anemia bagi ibu hamil serta melakukan kegiatan screening anemia dengan pengecekan $\mathrm{Hb}$ minimal dua kali selama kehamilan.
\end{abstract}

Kata Kunci:Anemia, Hamil, Trimester III, Haemoglobin

Anemia adalah masalah kesehatan masyarakat dunia yangdapat meningkatkan angkamorbiditas dan mortalitas. Angkaprevalensi anemia masih tinggi,dibuktikan dengan data World HealthOrganization (WHO) 2010, yaitusecara global prevalensi anemiapada ibu hamil di seluruh duniaadalah sebesar $(41,8 \%)$. Prevalensi anemia pada ibu hamil diperkirakan di Asia sebesar (48,2\%), Afrika $(57,1 \%)$,Amerika $(24,1 \%)$ dan Eropa $(25,1 \%)$. Dinegara-negara berkembang adasekitar (40\%) kematian ibu berkaitan dengan anemia dalam kehamilan. Kebanyakan anemia dalamkehamilan 
disebabkan oleh defisiensibesi dan pendarahan akut, bahkan,jarak keduanya saling berinteraksi (Ariyani,2016).

Menurut encyclopedia of nations Indonesia berada di peringkat ke-58 dengan prevalensi anemia pada ibu hamil sebanyak (44,3\%) (Azra, 2015). Berdasarkan Riset Kesehatan Dasar (Riskesdas) tahun 2007 prevalensi anemia ibu hamil sebanyak (24,5\%) sedangkan Riskesdas 2013 prevalensi anemia ibu hamil $(37,1 \%)$, angka ini jelas menjelaskan bahwa terjadi peningkatan kejadian anemia pada ibu hamil di Indonesia.

Anemia gizi besi pada ibu hamil masih merupakan salah satu masalah kesehatan masyarakat di Indonesia dimana angka kematian ibu hamil yang cukup tinggi.Penyebab utama anemia ini adalah kekurangan zat besi.Selama kehamilan terjadi peningkatan kebutuhan zat besi hampir tiga kali lipat untuk pertumbuhan janin dan keperluan ibu hamil.Konsekuensi anemia pada ibu hamil dapat membawa pengaruh buruk baik terhadap kesehatan ibu maupun janinnya, keadaan ini dapat meningkatkan morbiditas maupun mortalitas ibu dan anak.Keadaan kurang zat besi $(\mathrm{Fe})$ merupakan fenomena yang kompleks (Khomsan, 2010).

Faktor-faktor yang mempengaruhi anemia ibu hamil diantaranya faktor internal dan eksternal.Faktor internal yakni pola makan, umur, usia kehamilan, paritas, jarak kehamilan, pengukuran lingkar lengan atas, penyakit infeksi, sedangkan faktor eksternal yakni, pendidikan, pengetahuan, tingkat ekonomi, pemeriksaan kehamilan dan suplementasi Fe. Diduga adanya faktorfaktor yang mempengaruhi anemia ibu hamil paling besar yakni usia ibu, sehingga angka kejadian anemia mengalami peningkatan dari tahun ke tahun misalnya angka paritas dan jarak kehamilan yang terlalu dekat (Zuandra,2016).

Data dinas kesehatan Kota Bengkulu menunjukkan bahwa angka kejadian anemia pada ibu hamil terus meningkat dari tahun ke tahun. Pada tahun 2013 prevalensi ibu hamil dengan anemia hanya $(2,31 \%)$, tahun 2014 meningkat lagi menjadi $(3,93 \%)$ dan di tahun 2015 angka prevalensi ibu hamil anemia meningkat drastis menjadi $(19,09 \%)$.

$$
\text { Penulis memilih melakukan }
$$

penelitian di Kecamatan Kampung Melayu Kota Bengkulu yang terdiri dari dua wilayah kerja puskesmas yaitu Puskesmas Kandang dan Puskesmas Padang Serai. Angka prevalensi anemia ibu hamil di Kecamatan Kampung Melayu adalah (20,76\%) di tahun 2015 dengan jumlah ibu hamil 886 ibu hamil dan yang memeriksakan haemoglobinnya 184 ibu hamil dan semua ibu hamil yang memeriksakan haemoglobinnya dinyatakan anemia bahkan 3 diantaranya termasuk anemia berat, artinya terdapat 709 ibu hamil yang tidak memeriksakan haemoglobinnya ke pelayanan kesehatan terdekat sehingga 
tidak terdeteksi adanya anemia atau tidak anemia. Pada tahun 2015 di Kecamatan Kampung Melayu menyumbang Angka Kematian Ibu (AKI) walaupun hanya 1 orang, namun AKI merupakan indikator derajat kesehatan masyarakat di Indonesia.

\section{BAHAN DAN CARA KERJA}

Rancangan penelitian ini menggunakan pendekatan cross sectional.Populasi dari penelitian ini adalah berjumlah 276 ibu hamil di Kecamatan Kampung Melayu Kota Bengkulu Tahun 2017. Teknik pengambilan sampel ini adalah total sampling dimana ibu hamil trimester III memenuhi kriteria berjumlah 106 ibu hamil.Waktu penelitian dilakukan pada bulan Mei-Juni 2017. Penelitian ini menggunakan data primer, yaitu pengisian kuisioner usia, paritas, pendidikan, pengetahuan, pekerjaan, pendapatan, konsumsi tablet $\mathrm{Fe}$ dan pemeriksaan kadar hemoglobin menggunakan $\mathrm{Hb}$ digital untuk menentukan anemia. Teknik pengumpulan data dengan komputasi yaitu editing, coding, entry, dan cleaning. Analisis data yang digunakan adalah analisa univariat, bivariat dan multivariat.

\section{HASIL}

\section{Analisis Univariat}

Tabel 1Distribusi frekuensikejadian anemia pada ibu hamil trimester III di Kecamatan Kampung Melayu Kota Bengkulu Tahun 2017.

\begin{tabular}{llcc}
\hline No & \multicolumn{1}{c}{ Variabel } & Frekuensi & \% \\
\hline 1. & Anemia & & \\
& Anemia & 78 & 72,6 \\
& Tidak Anemia & 28 & 26,4 \\
2. & Usia & 14 & 13,2 \\
& $<20$ tahun dan $>35$ & 92 & 86,8 \\
& tahun & & \\
& 220 tahun-35 & & \\
& tahun & & 40,6 \\
3. & Paritas & 43 & 59,4 \\
& Multipara/Grande & 63 & \\
& multipara & & \\
& Primipara & & \\
\hline
\end{tabular}

\begin{tabular}{|c|c|c|c|}
\hline \multirow[t]{3}{*}{4.} & Pendidikan & & \\
\hline & Rendah (SD/SMP) & 62 & 58,5 \\
\hline & $\begin{array}{l}\text { Menengah/Tinggi } \\
\text { (SMA/PT) }\end{array}$ & 44 & 41,5 \\
\hline \multirow[t]{4}{*}{5.} & Pengetahuan & & \\
\hline & Kurang (benar & 60 & 56,6 \\
\hline & $\leq 50 \%)$ & 46 & 43,4 \\
\hline & $\begin{array}{l}\text { Cukup (benar } \\
<50 \% \text { ) }\end{array}$ & & \\
\hline \multirow[t]{3}{*}{6.} & Pekerjaan & & \\
\hline & Tidak Bekerja & 79 & 74,5 \\
\hline & Bekerja & 27 & 25,5 \\
\hline \multirow[t]{5}{*}{7} & Pendapatan & & \\
\hline & Rendah & 69 & 65,1 \\
\hline & $(\mathrm{UMR}<1.730 .000)$ & 37 & 34,9 \\
\hline & Cukup & & \\
\hline & $(\mathrm{UMR} \geq 1.730 .000)$ & & \\
\hline \multirow[t]{5}{*}{8.} & Konsumsi Tablet & & \\
\hline & $\mathrm{Fe}$ & 83 & 78,3 \\
\hline & Kurang & 23 & 21,7 \\
\hline & Cukup & & \\
\hline & JUMLAH & 106 & 100 \\
\hline
\end{tabular}

$\overline{\text { Berdasarkan tabel } 1 \text { di atas diketahui bahwa }}$ dari 106 ibu hamil trimester IIIdi Kecamatan Kampung Melayu Kota Bengkulu Tahun 2017bahwa sebagian besar (72,6\%) yang anemia, sebagian kecil $(13,2 \%)$ usia ibu berisiko, hampir sebagian (40,6\%) yang Multipara / Grandemultipara, sebagian besar $(58,5 \%)$ pendidikan adalah rendah, sebagian besar $(56,6 \%)$ pengetahuan kurang, sebagian tidak bekerja $(75,5 \%)$, ibu hamil sebagian besar berpendapatan rendah $(65,1 \%)$ dan hampir seluruh kurang mengkonsumsi tablet $\mathrm{Fe}(78,3 \%)$.

\section{Analisis Bivariat}

Tabel 2Hubungan Usia dengan Anemia pada Ibu Hamil Trimester III di Kecamatan Kampung Melayu tahun 2017.

\begin{tabular}{|c|c|c|c|c|c|c|c|c|}
\hline \multirow{3}{*}{$\begin{array}{l}\text { Usia } \\
\text { ibu }\end{array}$} & \multicolumn{4}{|c|}{ Anemia } & \multirow{2}{*}{\multicolumn{2}{|c|}{ Jumlah }} & \multirow{3}{*}{$\begin{array}{c}P \\
v a \\
l u \\
e\end{array}$} & \multirow{3}{*}{$\begin{array}{c}\text { OR } \\
(95 \% \mathrm{CI} \\
)\end{array}$} \\
\hline & \multicolumn{2}{|c|}{ Anemia } & \multicolumn{2}{|c|}{$\begin{array}{c}\text { Tidak } \\
\text { Anemia }\end{array}$} & & & & \\
\hline & $\mathrm{N}$ & $\%$ & $\mathrm{~N}$ & $\%$ & $\mathrm{~N}$ & $\%$ & & \\
\hline $\begin{array}{l}<20 \\
\text { dan } \\
>35 \text { th }\end{array}$ & $\begin{array}{l}1 \\
2\end{array}$ & 85,7 & 2 & 14,3 & $\begin{array}{l}1 \\
4\end{array}$ & 100 & 0 & 2,364 \\
\hline $\begin{array}{l}20- \\
35 \text { th }\end{array}$ & $\begin{array}{l}6 \\
6\end{array}$ & 71,7 & 26 & 28,3 & $\begin{array}{l}9 \\
2\end{array}$ & 100 & $\begin{array}{l}3 \\
4\end{array}$ & $\begin{array}{l}(0,495- \\
11,296)\end{array}$ \\
\hline $\begin{array}{l}\text { Juma } \\
\text { h }\end{array}$ & $\begin{array}{l}7 \\
8\end{array}$ & 73,6 & 28 & 26,4 & $\begin{array}{l}1 \\
0 \\
6\end{array}$ & 100 & 6 & \\
\hline
\end{tabular}

analisis bivariat ibu hamil trimester III yang 
memiliki 14 orang yang memiliki usia berisiko terdapat sebagian besar $(85,7 \%)$ ibu hamil trimester III yang anemia dan sebagian kecil $(14,3 \%)$ ibu hamil anemia berusia $<20$ dan >35 tahun dengan hasil chi square yang di dapat $\mathrm{p}=0,346>0,05$ yang berarti tidak terdapat hubungan antara usia ibu hamil dengan kejadian anemia ibu hamil trimester III.

Tabel 3Hubungan Paritas dengan Anemia pada Ibu Hamil Trimester III di Kecamatan Kampung Melayu tahun 2017

\begin{tabular}{|c|c|c|c|c|c|c|c|c|}
\hline \multirow{3}{*}{$\begin{array}{c}\text { Parita } \\
\text { s }\end{array}$} & \multicolumn{4}{|c|}{ Anemia } & \multirow{2}{*}{\multicolumn{2}{|c|}{ Jumlah }} & \multirow{3}{*}{$\begin{array}{c}P \\
v a \\
l u \\
e\end{array}$} & \multirow{3}{*}{$\begin{array}{c}\mathrm{OR} \\
(95 \% \mathrm{C} \\
\mathrm{I})\end{array}$} \\
\hline & \multicolumn{2}{|c|}{ Anemia } & \multicolumn{2}{|c|}{$\begin{array}{c}\text { Tidak } \\
\text { Anemia }\end{array}$} & & & & \\
\hline & $\mathrm{N}$ & $\%$ & $\mathrm{~N}$ & $\%$ & $\mathrm{~N}$ & $\%$ & & \\
\hline Multi & & & & & & & & \\
\hline $\begin{array}{l}\text { /Gran } \\
\text { demul } \\
\text { tipara }\end{array}$ & 31 & 72,1 & 12 & 27,9 & 43 & 100 & $\begin{array}{l}0, \\
94\end{array}$ & $\begin{array}{c}0,879 \\
(0,367\end{array}$ \\
\hline $\begin{array}{l}\text { Primi } \\
\text { Para }\end{array}$ & 47 & 74,6 & 16 & 25,4 & 63 & 100 & 9 & $2, \overline{110})$ \\
\hline $\begin{array}{l}\text { Jum } \\
\text { lah }\end{array}$ & 78 & 73,6 & 28 & 26,4 & $\begin{array}{c}10 \\
6\end{array}$ & 100 & & \\
\hline
\end{tabular}

hamil trimester III yang memiliki paritas Multipara / Grandemultipara adalah 43 orang dan sebagian besar

\begin{tabular}{rc}
\hline Anemia & Tidak \\
& Anemia
\end{tabular}

$(72,1 \%)$ ibu hamil trimester III anemia sedangkan sebagian kecil ibu hamil trimester III $(27,9 \%)$ anemia dengan hasil chi square di dapat $p=0,949>0,05$ yang berarti tidak ada hubungan antara paritas dengan ke jadian anemia ibu hamil trimester III.

Tabel 4 Hubungan Pendidikan dengan Anemia pada Ibu Hamil Trimester III di Kecamatan Kampung Melayu tahun 2017

\begin{tabular}{|c|c|c|c|c|c|c|c|c|}
\hline \multirow{3}{*}{$\begin{array}{l}\text { Pendi } \\
\text { Dikan }\end{array}$} & \multicolumn{4}{|c|}{ Anemia } & & & \multirow{3}{*}{$\begin{array}{c}P \\
v a l \\
u e\end{array}$} & \multirow{3}{*}{$\begin{array}{c}\text { OR } \\
(95 \% \\
\mathrm{CI})\end{array}$} \\
\hline & \multicolumn{2}{|c|}{ Anemia } & \multicolumn{2}{|c|}{$\begin{array}{c}\text { Tidak } \\
\text { Anem } \\
\text { ia }\end{array}$} & JuI & & & \\
\hline & $\mathrm{n}$ & $\%$ & $\mathrm{~N}$ & $\%$ & $\mathrm{~N}$ & $\%$ & & \\
\hline $\begin{array}{l}\text { Renda } \\
\text { h }\end{array}$ & 49 & $\begin{array}{l}7 \\
9\end{array}$ & $\begin{array}{l}1 \\
3\end{array}$ & $\begin{array}{l}2 \\
1\end{array}$ & $\begin{array}{l}6 \\
2\end{array}$ & $\begin{array}{l}1 \\
0 \\
0\end{array}$ & 0,1 & 1,950 \\
\hline
\end{tabular}

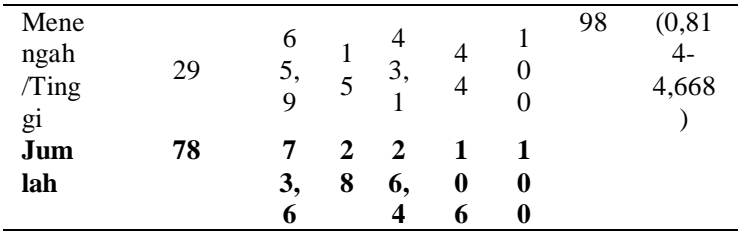

Berdasarkan tabel 4 terdapat ibu hamil trimester III yang memiliki pendidikan rendah (SD/SMP) berjumlah 62 orang dan sebagian besar ibu hamil (79\%) berpendidikan rendah dengan anemia dan sebagian kecil (21\%) ibu hamil anemia dengan hasil chi square yang di dapat $\mathrm{p}=0,198>0,05$ yang berarti tidak ada hubungan antara pendidikan dengan anemia trimester III.

Tabel 5 Hubungan Pengetahuan dengan Anemia pada Ibu Hamil Trimester III di Kecamatan Kampung Melayu tahun 2017

\begin{tabular}{|c|c|c|c|c|c|c|c|c|}
\hline \multirow{4}{*}{$\begin{array}{c}\text { Peng } \\
\mathrm{e} \\
\text { tahua } \\
\mathrm{n}\end{array}$} & \multirow{2}{*}{\multicolumn{4}{|c|}{ Anemia }} & \multicolumn{4}{|c|}{$P$} \\
\hline & & & & & \multicolumn{2}{|c|}{ Jumlah } & $v$ & \multirow{3}{*}{$\begin{array}{c}\text { OR } \\
(95 \% \\
\mathrm{CI})\end{array}$} \\
\hline & \multicolumn{2}{|c|}{ Anemia } & \multicolumn{2}{|c|}{$\begin{array}{c}\text { Tidak } \\
\text { Anemia }\end{array}$} & \multirow[b]{2}{*}{$\mathrm{N}$} & \multirow[b]{2}{*}{$\%$} & \multirow{2}{*}{$\begin{array}{l}a l \\
u \\
e\end{array}$} & \\
\hline & $\mathrm{n}$ & $\%$ & $\mathrm{~N}$ & $\%$ & & & & \\
\hline $\begin{array}{l}\text { Kura } \\
\text { ng }\end{array}$ & $\begin{array}{l}5 \\
4\end{array}$ & 90 & 6 & 10 & 60 & 100 & 0 & $\begin{array}{l}8,250 \\
(2,967-\end{array}$ \\
\hline Cuku & 2 & 52 , & 2 & 47, & 46 & 100 & 0 & $22,942)$ \\
\hline $\mathrm{p}$ & 4 & 2 & 2 & 8 & 40 & 100 & 0 & \\
\hline Jum & 7 & 73 , & 2 & 57, & 106 & 100 & 0 & \\
\hline lah & 8 & 6 & 8 & 8 & & & & \\
\hline
\end{tabular}

hamil trimester III yang memiliki pengetahuan yang kurang berjumlah 60 orang dan hampir seluruh ibu hamil (90\%) berpengetahuan kurang dengan anemia dengan dan sebagian kecil (10\%) ibu hamil tidak anemia dengan hasil chi square yang di dapat nilai $\mathrm{p}=0,000<0,05$ yang berarti ada hubungan bermakna antara pengetahuan dengan anemia ibu hamil trimester III dengan nilai OR 8,250 (CI 2,967-22,942). Nilai OR menunjukkan pengetahuan ibu hamil yang kurang mempunyai faktor resiko 
8,250 kali lebih besar daripada ibu hamil yang pengetahuannya kurang.

Tabel 6Hubungan Pekerjaan dengan Anemia pada Ibu Hamil Trimester III di Kecamatan Kampung Melayu tahun 2017

\begin{tabular}{|c|c|c|c|c|c|c|c|c|}
\hline \multirow{3}{*}{$\begin{array}{c}\text { Peker } \\
\text { jaan }\end{array}$} & \multicolumn{4}{|c|}{ Anemia } & \multirow{2}{*}{\multicolumn{2}{|c|}{ Jumlah }} & \multirow{3}{*}{$\begin{array}{c}P \\
v a \\
l u \\
e\end{array}$} & \multirow{3}{*}{$\begin{array}{c}\text { OR } \\
(95 \% \\
\text { CI })\end{array}$} \\
\hline & \multicolumn{2}{|c|}{ Anemia } & \multicolumn{2}{|c|}{$\begin{array}{c}\text { Tidak } \\
\text { Anemia }\end{array}$} & & & & \\
\hline & $\mathrm{N}$ & $\%$ & $\mathrm{~N}$ & $\%$ & $\mathrm{~N}$ & $\%$ & & \\
\hline Tidak & & & & & & & & \\
\hline $\begin{array}{l}\text { Beker } \\
\text { ja }\end{array}$ & 58 & 73,4 & 21 & 26,6 & 79 & 100 & $\begin{array}{l}1, \\
00\end{array}$ & $\begin{array}{l}0,967 \\
(0,357\end{array}$ \\
\hline $\begin{array}{l}\text { Beker } \\
\text { ja }\end{array}$ & 20 & 74,1 & 7 & 25,9 & 27 & 100 & 0 & $\begin{array}{c}- \\
2,615)\end{array}$ \\
\hline $\begin{array}{l}\text { Jum } \\
\text { lah }\end{array}$ & 78 & 73,6 & 18 & 26,4 & $\begin{array}{c}10 \\
6\end{array}$ & 100 & & \\
\hline
\end{tabular}

Berdasarkan tabel 6 terdapat ibu hamil trimester III yang tidak bekerja berjumlah 79 orang dan sebagian besar ibu hamil $(73,4 \%)$ dengan anemia dan sebagian kecil ibu hamil (26,6\%) tidak anemia dengan hasil chi square yang di dapat nilai $p=1,00>$ 0,05 yang berarti tidak ada hubungan antara pekerjaan dengan anemia ibu hamil trimester III.

Tabel 7 Hubungan Pendapatan dengan Anemia pada Ibu Hamil Trimester III di Kecamatan Kampung Melayu tahun 2017

\begin{tabular}{|c|c|c|c|c|c|c|c|c|}
\hline \multirow{3}{*}{$\begin{array}{c}\text { Penda } \\
\text { patan }\end{array}$} & \multicolumn{4}{|c|}{ Anemia } & \multirow{2}{*}{\multicolumn{2}{|c|}{ Jumlah }} & \multirow{3}{*}{$\begin{array}{c}P \\
v a \\
l u \\
e\end{array}$} & \multirow{3}{*}{$\begin{array}{c}\text { OR } \\
(95 \% \\
\text { CI })\end{array}$} \\
\hline & \multicolumn{2}{|c|}{ Anemia } & \multicolumn{2}{|c|}{$\begin{array}{c}\text { Tidak } \\
\text { Anemia }\end{array}$} & & & & \\
\hline & $\mathrm{N}$ & $\%$ & $\mathrm{~N}$ & $\%$ & $\mathrm{~N}$ & $\%$ & & \\
\hline $\begin{array}{l}\text { Renda } \\
\mathrm{h}\end{array}$ & 52 & $\begin{array}{l}75 \\
4\end{array}$ & 17 & 24,6 & 69 & 100 & 0 & 1,294 \\
\hline $\begin{array}{l}\text { Cuku } \\
\text { p }\end{array}$ & 26 & $\begin{array}{l}70 \\
, 3\end{array}$ & 11 & 29,7 & 37 & 100 & $\begin{array}{c}73 \\
7\end{array}$ & $\begin{array}{l}(0,530- \\
3,160)\end{array}$ \\
\hline $\begin{array}{l}\text { Jum } \\
\text { lah }\end{array}$ & 78 & $\begin{array}{l}73 \\
, 6\end{array}$ & 28 & 24,6 & 106 & 100 & & \\
\hline
\end{tabular}

Berdasarkan tabel 7 terdapat ibu

hamil trimester III yang perpendapatan rendah berjumlah 69 orang dan sebagian besar ibu hamil $(75,4 \%)$ anemia dan sebagian kecil $(24,6 \%)$ ibu hamil tidak anemia dengan hasil chi square yang di dapat yaitu nilai $p=0,737>0,05$ yang berarti tidak terdapat hubungan antara pendapatan dengan anemia ibu hamil trimester III.

Tabel 8Hubungan Konsumsi Tablet Fe dengan Anemia pada Ibu Hamil Trimester III di Kecamatan Kampung Melayu Kota Bengkulu Tahun 2017

\begin{tabular}{|c|c|c|c|c|c|c|c|c|}
\hline \multirow{2}{*}{$\begin{array}{c}\text { Kon } \\
\text { sumsi } \\
\text { Tablet } \\
\text { Fe }\end{array}$} & \multicolumn{4}{|c|}{ Anemia } & \multicolumn{2}{|c|}{ Jumlah } & \multirow{2}{*}{$\begin{array}{l}P \\
V \\
a l \\
\text { ue }\end{array}$} & \multirow{2}{*}{$\begin{array}{c}\text { OR } \\
(95 \\
\% \mathrm{CI} \\
)\end{array}$} \\
\hline & $\mathrm{N}$ & $\%$ & $\mathrm{~N}$ & $\%$ & $\mathrm{~N}$ & $\%$ & & \\
\hline $\begin{array}{l}\text { Kuran } \\
\mathrm{g}\end{array}$ & 76 & 91,6 & 7 & 8,4 & 83 & 100 & $\begin{array}{l}0, \\
00\end{array}$ & 114 \\
\hline $\begin{array}{l}\text { Cuku } \\
\mathrm{p}\end{array}$ & 2 & 8,7 & 21 & 91,3 & 23 & 100 & 0 & 000 \\
\hline $\begin{array}{l}\text { Jum } \\
\text { lah }\end{array}$ & 78 & 73,6 & 28 & 26,4 & 106 & 100 & & $\begin{array}{l}024- \\
590, \\
089)\end{array}$ \\
\hline
\end{tabular}

Berdasarkan tabel 8 terdapat ibu

hamil trimester III yang kurang mengkonsumsi tablet $\mathrm{Fe}$ (sisa $\geq 18$ dari 90 tablet $\mathrm{Fe}$ ) berjumlah 83 orang dan sebagian besar ibu hamil $(91,6 \%)$ anemia dan sebagian kecil $(8,4 \%)$ ibu hamil tidak anemia dengan hasil chi square yang di dapat yaitu nilai $p=0,00<0,05$ yang berarti ada hubungan yang bermakna antara konsumsi tablet Fe dengan anemia ibu hamil trimester III dengan nilai $\mathrm{OR}=114,000$, artinya ibu hamil trimester III yang kurang mengkonsumsi tablet Fe mempunyai peluang 114 kali berisiko anemia dibandingkan ibu hamil yang cukup mengkonsumsi tablet Fe.

\section{Hasil Multivariat}

Tabel 9 Hasil Uji Regresi Logistik Faktor yang Paling Dominan Mempengaruhi Variabel Dependen

\begin{tabular}{|c|c|c|c|}
\hline Variabel & $\begin{array}{c}\mathbf{P} \\
\text { Value }\end{array}$ & OR & $\begin{array}{c}\text { 95\% C.I for } \\
\operatorname{Exp}(\mathrm{B})\end{array}$ \\
\hline Pengetahuan & 0,079 & 3,543 & $0,862-14,566$ \\
\hline Konsumsi Tablet Fe & 0,000 & $\begin{array}{l}78,80 \\
3\end{array}$ & $14,783-420,089$ \\
\hline
\end{tabular}

Dari analisis multivariat ternyata variabel yang berhubungan adalah konsumsi tablet $\mathrm{Fe}$, variabel ini telah di kontrol oleh 
variabel pengetahuan. Hasil analisis umur tersebut kurang berisiko komplikasi didapatkan Odds Ratio dari variabel kehamilan serta memiliki reproduksi yang konsumsi tablet Fe adalah 78,803 artinya ibu sehat.Hal ini terkait dengan kondisi biologis hamil trimester III dapat mengalami anemia dan psikologis dari ibu hamil.Sebaliknya 78,803 kali lebih tinggi dibandingkan ibu pada kelompok umur $<20$ tahun berisiko yang mengkonsumsi tablet fe cukup. Ini berarti bahwa faktor yang paling anemia sebab pada kelompok umur tersebut berpengaruh terhadap anemia ibu hamil trimester III adalah konsumsi tablet Fe.

\section{PEMBAHASAN}

Hubungan Usia dengan Anemia pada Ibu Hamil Trimester III

Hasil penelitian ini didapat $\mathrm{p}=0,346>$

0,05 yang berarti tidak terdapat hubungan antara usia ibu hamil dengan kejadian anemia ibu hamil trimester III. Hal ini dapat terjadi karena ibu hamil trimester III tersebut terdapat banyakusia yang tidak berisiko dan masih terdapat banyak faktor lain yang dapat menyebabkan anemia pada ibu hamil trimester III.

Penelitian ini menunjukkan bahwa usia tidak termasuk ke dalam faktor yang berhubungan dengan anemia pada ibu hamil. Hal ini disebabkan seseorang yang berusia $<20$ dan >35 tahun belum tentu mengalami anemia pada kehamilannya. Berdasarkan penelitian ini, didapat 78 ibu hamil yang anemia dari 106 ibu hamil trimester III yang terdiri dari $12 \mathrm{ibu}$ hamil berusia $<20$ dan $>35$ dan 66 ibu hamil yang berusia 20-35 tahun. Sedangkan menurut Manuaba et al (2007), umur ibu yang ideal dalam kehamilan yaitu pada kelompok umur 20-35 tahun dan pada perkembangan biologis yaitu reproduksi belum optimal. Selain itu, kehamilan pada kelompok usia diatas 35 tahun merupakan kehamilan yang beresiko tinggi. Wanita hamil dengan umur diatas 35 tahun juga akan rentan anemia. Hal ini menyebabkan daya tahan tubuh mulai menurun dan mudah terkena berbagai infeksi selama masa kehamilan.

Penelitian ini terdapat $12 \mathrm{ibu}$ hamil berusia yang anemia dan 2 ibu hamil yang tidak anemia.Sedangkan 12 ibu hamil yang anemia tersebut ternyata juga berpengetahuan rendah. Penelitian ini menunjukkan bahwa kurangnya pengetahuan ibu hamil lebih berhubungan dengan anemia daripada usia karena berdasarkan penelitian tidak ada hubungannya antara usia yang <20 dan $>35$ tahun maupun usia 20 - 35 tahun dengan anemia ibu hamil trimester III. Hal ini disebabkan kondisi Kecamatan Kampung Melayu yang letaknya berada di pinggiran kota dan beberapa wilayah Kecamatan Kampung Melayu belum terjangkau dengan layanan kesehatan sehingga banyak informasi-informasi terkait seputar kesehatan termasuk hal-hal mengenai anemia pada kehamilan sebagai salah satu tanda bahaya 
kehamilan belum banyak diterima masyarakat termasuk ibu hamil.

Hubungan Paritas dengan Anemia pada Ibu Hamil Trimester III

Hasil penelitianini di dapat bahwa nilai $\mathrm{p}=0,949>0,05$ yang berarti tidak ada hubungan antara paritas dengan kejadian anemia ibu hamil trimester III di Kecamatan Kampung Melayu Tahun 2017.Hasil penelitian ini sejalan dengan penelitian Pane (2015) yang dilakukan pada ibu hamil di Kelurahan Bandar Selamat Kecamatan Medan Tembung Tahun 2015. Hasil penelitiannnya menunjukkan bahwa tidak ada hubungan paritas dengan kejadian anemia pada ibu hamil $(\mathrm{p}=0,622)$.

Penelitian yang telah dilakukan di Kecamatan Kampung Melayu Kota Bengkulu tahun 2017 membuktikan bahwa faktor paritas tidak termasuk salah satu faktor yang berhubungan dengan anemia pada ibu hamil trimester III .

\section{Hubungan Pendidikan dengan Anemia pada Ibu Hamil Trimester III}

Hasil penelitian ini menunjukkannilai $p$ yang di dapat di dapat $p=0,198>0,05$ yang berarti tidak ada hubungan antara pendidikan dengan anemia trimester III.Hal ini dapat terjadi karena ibu hamil trimester III tersebut hanya sebagian yang berpendidikan rendah dan masih terdapat banyak faktor lain yang dapat menyebabkan anemia pada ibu hamil trimester III .
Hasil penelitian ini sama dengan penelitian Adipati (2013), penelitian yang dilakukan pada ibu hamil di Puskesmas Bahu Kecamatan Malalayang Kota Manado, yaitu tidak ada hubungan yang signifikan antara pendidikan dengan kejadian anemia $(\mathrm{p}=$ $0,543)$.

Makin tinggi pendidikan makin tinggi pula kesadaran ibu untuk mendapatkan gizi yang baik sehingga tidak menimbulkan anemia pada kehamilan.Ibu hamil anemia dengan pendidikan rendah prevalensinya lebih besar daripada ibu yang berpendidikan tinggi. Pendidikan erat dengan kemampuan menerima informasi yang berkaitan dengan kesehatan terutama pada ibu hamil anemia, seperti pengetahuan anemia, pemilihan makanan tinggi zat besi dan asupan zat besi (Mariza,2016).

Hasil penelitian menunjukkan bahwa pendidikan tidak termasuk dalam faktor yang mempengaruhi kejadian anemia pada ibu hamil trimester III.Seseorang yang berpendidikan menengah atau tinggi belum tentu mengerti mengenai pengetahuan tentang bahaya anemia pada ibu hamil dan seseorang yang berpendidikan rendah belum tentu tidak mampu dalam penyusunan makanan bergizi, orang-orang yang berpendidikan rendah bisa saja mendapatkan informasi melalui media, sesama ibu hamil, puskesmas dan posyandu. Rasa ingin tahu ibu hamil yang tinggi dapat merubah pola pikir 
ibu untuk memenuhi kebutuhan gizinya selama hamil.

Hubungan Pengetahuan dengan Anemia pada

\section{Ibu Hamil III}

Hasil penelitian ini didapat nilai $\mathrm{p}=0,000<0,05$ yang berarti ada hubungan bermakna antara pengetahuan dengan anemia ibu hamil trimester III di Kecamatan Kampung Melayu Kota Bengkulu Tahun 2017.

Penelitian ini sejalan dengan hasil penelitian Pane (2015), bahwa ada hubungan pengetahuan ibu hamil dengan kejadian anemia pada ibu hamil $(\mathrm{p}=0,000)$, penelitian dilakukan pada ibu hamil di Kelurahan Bandar Selamat Kecamatan Medan Tembung. Sama hasilnya dengan penelitian Kurniati (2016), hasil penelitian menunjukkan ada hubungan antara pengetahuan dengan kejadian anemia $(\mathrm{p}=0,002)$. Penelitian ini dilakukan pada ibu hamil di Kabupaten Pemalang.

Ibu hamil yang mempunyai pengetahuan kurang tentang anemia akan berperilaku negatif, sedangkan ibu hamil yang negatif sedangkan ibu hamil yang berpengetahuan baik akan berperilaku positif. Hal ini adalah perilaku untuk mencegah atau mengobati anemia.Oleh karena itu diperlukan peningkatan pengetahuan tentang anemia kehamilan.Hal ini sejalan dengan pendapata Kurniati (2016), peningkatan pengetahuan ibu hamil ini dapat dilakukan dengan cara penyuluhan yang berdasarkan karakteristriknya agar materi penyuluhan dapat diterima oleh ibu hamil meskipun karakteristriknya berbeda. Misalnya pemberian pendidikan kepada ibu hamil yang pengetahuannya rendah menggunakan cara berbeda dengan penyuluhan yang dilakukan pada ibu hamil yang berpendidikan tinggi.

\section{Hubungan Pekerjaan dengan Anemia pada}

\section{Ibu Hamil Trimester III}

Hasil penelitian adalah $\mathrm{p}=1,00>$ 0,05 yang berarti tidak ada hubungan antara pekerjaan dengan anemia ibu hamil trimester III.Hasil penelitian ini sama dengan penelitian yang dilakukan Handayani (2012), yaitu tidak ada hubungan yang signifikan antara status pekerjaan dengan kejadian anemia ibu hamil trimester III di Wilayah Puskesmas Liang Anggang Kota Banjar Baru dengan nilai $\mathrm{p}=0,279>0,05$. Penelitian yang dilakukan oleh Azra dan Rosha (2015) sama hasilnya dengan penelitian ini, hasil yang di dapat adalah nilai $\mathrm{p}=0,76>0,05$, maka tidak ada hubungan yang bermakna antara pekerjaan dengan status anemia ibu hamil di Puskesmas Air Dingin Koto Tangah Padang. Lingkungan pekerjaan dapat membuat seseorang memperoleh pengalaman dan pengetahuan, baik secara langsung maupun tidak langsung (Mubarak, 2011).Pekerjaan adalah simbol status seseorang dimasyarakat.Pekerjaan 
jembatanuntuk memperoleh uang dalam rangka mememuhi kebutuhan hidupnya, jadi semakin banyak jumlah anak maka semakin banyak pula biaya yang di butuhkan. Maka semakin besar beban kerja ibu untuk memenuhi kebutuhan hidup (Suparyanto, 2010).

Penelitian ini tidak sejalan dengan penelitian yang dilakukan Anggraini \& Sari (2015), penelitian ini dilakukan padaibuhamil di Puskesmas Basuki Rahmat Palembang Tahun 2015.Hasil penelitian ini menunjukkan ada hubungan yang bermakna antara pekerjaan dengan kejadian anemia pada ibu hamil di Puskesmas Basuki Rahmat Palembang Tahun 2015 ( $\mathrm{p}=0,006)$.

Penelitian ini membuktikan bahwa tidak ada hubungan antara pekerjaan dengan anemia ibu hamil trimester III. Karakteristik penduduk Kecamatan Kota Bengkulu mayoritas adalah tidak bekerja, akan tetapi ibu hamil yang bekerja bukan berarti tidak mengalami anemia. Karena masih banyak faktor lainnya yang berhubungan dengan anemia ibu hamil trimester III di Kecamatan Kampung Melayu tahun 2013.

\section{Hubungan Pendapatan dengan Anemia pada Ibu Hamil Trimester III}

Hasil penelitian menunjukkan bahwa nilai $\mathrm{p}$ yang di dapat yaitu nilai $\mathrm{p}=0,737>$ 0,05 yang berarti tidak terdapat hubungan antara pendapatan dengan anemia ibu hamil trimester III. Hal ini dapat terjadi karena hampir sebagian ibuhamil trimester III yang bependapatan tinggi tersebut juga mengalami anemia dan masih terdapat banyak faktor lain yang dapat menyebabkan anemia pada ibu hamil trimester III selain faktor pendapatan rendah.

Hasil penelitian ini sejalan dengan penelitian yang dilakukan oleh Yanti et al (2016), penelitian ini dilakukan di Wilayah Kerja Puskesmas Liang Anggang Kota Banjar Baru Kalimantan Selatan. Hasil penelitiannya adalah tidak ada hubungan antara pendapatan dengan anemia pada ibu hamil $(\mathrm{p}=0,377)$,

Penelitian ini tidak sejalan hasilnya dengan penelitian yang dilakukan Kurniati (2016), hasil penelitian ini menunjukkan adanya hubungan tidak langsung yang positif pendapatan keluarga dengan anemia di Kabupaten Pemalang.

Penelitian ini membuktikan bahwa tidak ada hubungan antara pendapatan dengan kejadian anemia ibu hamil, walaupun karakteristik penduduk di Kecamatan Kampung Melayu Kota Bengkulu berpendapatan rendah akan tetapi belum tentu ibu hamil yang berpendapatan rendah saja yang dapat mengalami anemia tetapi ibu hamil yang berpenghasilan cukup pun juga bisa terkena anemia.

Hubungan Konsumsi Tablet $\mathrm{Fe}$ dengan Anemia pada Ibu Hamil Trimester III

Hasil penelitian ini adalah $\mathrm{p}=0,00>$

0,05 bahwa terdapat hubungan yang signifikan antara konsumsi tablet Fe dengan 
anemia iu hamil trimester III di Kecamatan Kampung Melayu Kota Bengkulu tahun 2017. Berdasarkan penelitian untuk mencari faktor yang paling berhubungan atau faktor yang paling dominan mempengaruhi anemia ibu hamil trimester III didapatkan nilai Exponen B (Odds Ratio) yaitu 78,803 yang artinya ibu hamil trimester III yang kurang mengkosumsi tablet $\mathrm{Fe} \quad 78,803$ kali dibandingkan ibu hamil yang cukup mengkonsumsi tablet $\mathrm{Fe}$ sampai trimester ketiga kehamilannya.

Penelitian ini sejalan dengan penelitian Pane (2015) pada ibu hamil di Kelurahan Bandar Selamat Kecamatan Medan Tembung Tahun 2015. Yaitu ada hubungan perolehan tablet zat besi $(\mathrm{Fe})$ yang diterima dan yang dikonsumsi dengan kejadian anemia pada ibu hamil $(\mathrm{p}=0,003)$. Sama hasilnya dengan penelitian Yanti et al (2015) di wilayah kerja Puskesmas tahun 2015. Hasil penelitian ini menunjukkan bahwa ada hubungan antara kepatuhan konsumsi tablet $\mathrm{Fe}$ dengan kejadian anemia kehamilan diperoleh nilai $(\mathrm{p}=0,000)$.

Penelitian pada wanita Denmark, suplemen $40 \mathrm{mg}$ zat besi ferrous / hari dari 18 minggu kehamilan tampaknya cukup untuk mencegah defisiensi zat besi pada $90 \%$ perempuan dan anemia kekurangan zat besi pada setidaknya $95 \%$ dari perempuan. Saat terbaik mengkonsumsi suplement Fe adalah sejak trimester 2 selama 90 hari kedepan (Susiloningtyas, 2016).
Faktor Yang Paling Dominan Berhubungan Dengan Anemia Ibu Hamil Trimester III

Dari hasil penelitian diperoleh konsumsi tablet $\mathrm{Fe}$ memiliki nilai eksponen B yang paling tinggi setelah di kontrol variabel pengetahuan yaitu 78,803 . Hal ini memberikan arti bahwa konsumsi tablet $\mathrm{Fe}$ merupakan faktor paling dominan yang berhubungan dengan anemia pada ibu hamil trimester III. Dikarenakan menurut pendapat Waryana (2010), saat kehamilan zat besi yang dibutuhkan oleh tubuh lebih banyak dibandingkan tidak hamil untuk memenuhi kehilangan basal, pembentukan sel-sel darah merah yang semakin banyak serta pertumbuhan dan perkembangan janin dan plasentanya. Dan didukung oleh pendapat Kristiyanansari (2010),Kebutuhan zat besi meningkat menjadi dua kali lipat bahkan lebih dibandingkan sebelum hamil yaitu naik dari 18 mg menjadi 30-60 mg perhari

Ibu hamil yang berpengetahuan cukup tentu akan berperilaku positif, hal ini dibuktikan dengan tingkat kepatuhan ibu hamil dalam mengkonsumsi tablet Fe. Sebagaimana menurut Susiloningtyas (2016), kepatuhan mengkonsumsi tablet besi adalah ketaatan ibu hamil dalam mengkonsumsi tablet besi sesuai dengan jumlah yang seharusnya diminum yaitu patuh jika mengkonsumsi $\geq 80 \%$ tablet besi yang seharusnya diminum dan tidak patuh jika mengkonsumsi $<80 \%$ tablet besi yang 
seharusnya diminum. Sehingga jumlah tablet

Fe minimal yang tersisa kurang dari 18 dari

90 tablet Fe yang seharusnya di konsumsi

ibu hamil trimester III. Sedangkan di

Kecamatan Kampung Melayu sebagian besar

ibu hamil kurang dalam mengkonsumsi tablet Fe.

\section{KESIMPULAN}

Sebagian besar ibu hamil trimester IIIyang anemia, sebagian kecil usia ibu berisiko, hampir sebagian yang Multipara / Grandemultipara, sebagian besar pendidikan adalah rendah, sebagian besar pengetahuan kurang, sebagian tidak bekerja, ibu hamil

\section{DAFTAR RUJUKAN}

Anggraini,Tirta dan Intan Sari.2015. Hubungan Antara Pekerjaan Dan Pendidikan Dengan Kejadian Anemia Pada Ibu Hamil Di Puskesmas Basuki Rahmat Palembang Tahun 2015.Jurnal. Palembang: Akbid Budi Mulia.

Bekele, et al. 2016. Prevalence of Anemia and Its Associated Factors among Pregnant Women Attending Antenatal Care in Health Institutions of Arba Minch Town, Gamo Gofa Zone, Ethiopia: A Cross-Sectional Study. indawi Publishing Corporation Anemia Volume 2016, Article ID 1073192,9 pageshttp://dx.doi.org/10.1155/2016/1073192

Departemen Kesehatan RI. 2013. Laporan Riset Kesehatan Dasar 2013.Jakarta: Badan Penelitian dan Pengembangan Kesehatan RI.

Dinas Kesehatan Kota Bengkulu.2016. Profil Dinas Kesehatan Kota Bengkulu Tahun 2015.Bengkulu.

Irianto, Koes.2014. Gizi Seimbang dalam Kesehatan Reproduksi (Balance Nutrision In Reproductive Health). Bandung: Alfabeta.

Kreibs, Jan M dan Carolyn L. Gegor. 2010. Buku Saku Asuhan Kebidanan Varney Edisi 2. Jakarta : Penerbit Buku EGC.

Kurniati, Ade. 2016. Pengaruh Pendidikan, Pendapatan Keluarga, Dan Interaksi Dengan Bidan Terhadap Kejadian Anemia Defisiensi Besi Pada Ibu Hamil Di Kabupaten sebagian besar berpendapatan rendah dan hampir seluruh kurang mengkonsumsi tablet. Ada hubungan antara kepatuhan konsumsi tablet $\mathrm{Fe}$ dan pengetahuan dengan kejadian anemia pada ibu hamil trimester III, tidak ada hubungan antara usia, paritas, pendidikan, pekerjaan dengan anemia dan faktor yang paling dominan dengan anemia adalah konsumsi tablet Fe.

Petugas kesehatan diharapkan memberikan penyuluhan rutin tentang, penyebab, gejala dan dampak anemia bagi ibu hamil serta melakukan kegiatan screening anemia dengan pengecekan $\mathrm{Hb}$ minimal dua kali selama kehamilan.

Pemalang.Tesis. Surakarta: Program Pascasarjana Universitas Sebelas Maret.

Manuaba, IBG et al.2007. Pengantar Kuliah Obstetri. Jakarta: EGC

Mariza, Ana.2016.Hubungan Pendidikan Dan Sosial Ekonomi Dengan Kejadian Anemia Pada Ibu Hamil Di Bps T Yohan Way Halim Bandar Lampung Tahun 2015.Jurnal Kesehatan Holistik Vol 10, No 1, Januari 2016 : 5-8Bandar Lampung : Program Studi Kebidanan Fk Universitas Malahayati

Mubarak, Wahid Iqbal. 2011. Promosi Kesehtan untuk Kebidanan. Jakarta: salemba medika.

Murti, Bhisma. 2010. Riwayat Alamiah Penyakit: Bab4.Http://fk.uns.ac.id/index.php/download/ file/14 (Di akses: 10 April 2017)

Obai et al. 2016. Prevalence of anaemia and associated risk factors among pregnant women attending antenatal care in Gulu and Hoima Regional Hospitals in Uganda: A cross sectional study. BioMed Central Pregnancy and Childbirth (2016) 16:76 DOI 10.1186/s12884016-0865-

Pane, Fitri Yani.2015.Faktor-Faktor Yang Berhubungan Dengan kejadian anemia Pada Ibu Hamil Di Kelurahan Bandar Selamat kecamatan medan Tembung Tahun 2015. Skripsi.Medan:Fakultas Kesehatan Masyarakat Universitas Sumatera Utara.

Setiawati, Sumini et al. 2013. Faktor-Faktor Yang Mempengaruhi Kejadian Anemia Pada Ibu Hamil Di Wilayah Kerja Puskesmas 
Sekampung Kabupaten Lampung Timur Tahun 2013. Jurnal Kesehatan Holistik vol 8, No 2, April 2014 : 53-58

Susiloningtyas, Is. 2016. Pemberian Zat Besi (Fe) dalam Kehamilan. Fakultas Ilmu Kesehatan Unissula. http://jurnal.unissula.ac.id/ (Di akses 25 maret 2017)

Yanti, Desi Ari Madi, et al. 2015. Faktor-Faktor Terjadinya Anemia Pada Ibu Primigravida Di Wilayah Kerja Puskesmas Pringsewu. Jurnal KeperawatanVolume 6 nomor 2.Lampung: Sekolah Tinggi Ilmu Kesehatan Muhammadiyah Pringsewu.
Zebua, Advince Mayasari. 2011.Faktor-Faktor Yang Berhubungan Dengan Kejadian Anemia Gizi Pada Ibu Hamil Di Wilayah Kerja Puskesmas Tuhemberua Kabupaten Nias Utara Tahun 2011. Skripsi. Ilmu Kesehatan Masyarakat. Medan: Universitas Sumatera Utara.

Zuandra, Risa Aprila.2016. Faktor-Faktor Yang Mempengaruhi Kejadian Anemia Ibu Hamil Di Puskesmas Ambacang Kecamatan Kuranji Kota Padang Tahun 2015. Padang: Kesehatan Masyarakat Universitas Andalas 